\title{
OCHRONA ZDROWIA DZIECKA I JEGO RODZINY A REALIZACJA OBOWIĄZKU NAUKI W SYTUACJI STANU EPIDEMII
}

\section{WPROWADZENIE}

Dbałość rodziców o dziecko jest przejawem naturalnej troski o jego bezpieczeństwo i prawidłowy rozwój. Zaangażowanie rodziców jest zachowaniem instynktownym niewymagajacym wyznaczania granic czy ram prawnych. Rodzice zapewniają dziecku opiekę, troszczą się o jego zdrowie i bezpieczeństwo. To naturalne prawo rodziców do wychowywania dziecka wynika z przysługującego im atrybutu ujętego w postaci władzy rodzicielskiej, związanego z urodzeniem (przysposobieniem) dziecka. Władza rodzicielska stanowi prawo naturalne, pierwotne, charakteryzujące się szerokim zakresem, który uwydatnia się w zróżnicowanych obszarach aktywności rodziców w życiu dziecka. Jej realizacja jest ściśle związana z wiekiem dziecka, z jego potrzebami i wraz $\mathrm{z}$ dorastaniem dziecka w naturalny sposób ulega zmianom. Jednym z elementów władzy rodzicielskiej jest piecza nad osobą i majątkiem dziecka. Piecza nad osobą obejmuje między innymi dbałość o fizyczny i duchowy rozwój dziecka i odnosi się do troski o jego zdrowie i bezpieczeństwo. Ten niemajątkowy obszar ochrony dziecka stanowi wartość podstawowa, którą regulacje międzynarodowe i krajowe otaczają ochroną przewidzianą dla wartości szczególnie cennych.

Zastrzeżona dla rodziców sfera autonomicznych decyzji dotyczacych dziecka podlega weryfikacji pod kątem ich pozytywnego wpływu na poszczególne obszary jego funkcjonowania i rozwoju, a jej ocena dokonywana jest przez pryzmat zasady dobra dziecka. W duchu tej samej zasady powinny być również oceniane, odniesione do dziecka, ustawowo regulowane obowiązki. Jednym $\mathrm{z}$ nich jest dbałość o edukację dziecka ujęta w postaci zarówno prawa, jak

* Kinga Michałowska, Uniwersytet Ekonomiczny w Krakowie, michalok@uek.krakow.pl, https://orcid.org/0000-0002-2133-8110. 
i obowiązku. Nie ulega wątpliwości, że prawo do nauki pozostaje w zgodności z zasadą dobra dziecka. Jako prawo gwarantowane konstytucyjnie i konwencyjnie daje podstawy do egzekwowania go w postaci nałożonego na rodziców dziecka obowiązku. Niemniej jego spełnienie musi być uzależnione od zapewnienia prawidłowych warunków jego realizacji. W związku z tym pojawia się pytanie, czy realizacja atrybutów władzy rodzicielskiej usprawiedliwia, wynikająca z zagrożeń związanych ze stanem epidemii, czasową odmowę realizacji przez dziecko obowiązku nauki, gdy warunki realizacji tego obowiązku moga stanowić zagrożenie dla zdrowia dziecka bądź członków jego rodziny.

\section{OCHRONA ZDROWIA I BEZPIECZEŃSTWA DZIECKA JAKO OBOWIĄZEK RODZICÓW}

Stanowiąca szczególne prawo podmiotowe władza rodzicielska jest przejawem autonomii rodziców. $\mathrm{Z}$ istoty władzy rodzicielskiej wynikają wskazane w art. 95 k.r.o. ${ }^{1}$ prawa i obowiązki rodziców względem dziecka, do których należą między innymi wykonywanie pieczy nad osobą i majątkiem dziecka oraz wychowywanie dziecka. Istota władzy rodzicielskiej, ze względu na swój charakter, wykazuje jako prawo podmiotowe szczególne cechy, a jej zasadniczą właściwość stanowi to, że jej atrybuty są zarazem obowiązkiem rodziców². Dualność zakresu władzy rodzicielskiej będąca źródłem nie tylko prawa, ale i obowiązków dostrzegalna jest między innymi w dbałości o dobro dziecka, w tym w zapewnienie mu ochrony przed niebezpieczeństwami ${ }^{3}$. W literaturze podkreśla się, że obowiązek ochrony realizuje się bez względu na źródło i rodzaj zagrożenia. Źródłem może być zarówno zagrożenie wewnętrzne, jak i zewnętrzne, niezależne od człowieka, wywołujące niebezpieczeństwo fizyczne i duchowe.

W sposobie ujęcia władzy rodzicielskiej, mimo powszechnie stosowanego zgodnie z regulacją kodeksową nazewnictwa, nie element władczy jest najistotniejszy, a cel, któremu realizacja władzy rodzicielskiej ma służyć. Orzecznictwo celu tego upatruje w ochronnej względem dziecka funkcji władzy rodzicielskiej5: ujmuje go jako dobro dziecka ${ }^{6}$, w jego aspekcie ocenia podejmowane w stosunku do dziecka decyzje i jednocześnie podkreśla pojemność klauzuli dobra dziecka7 ${ }^{7}$. Wykonując władzę rodzicielską, rodzice wycho-

\footnotetext{
${ }^{1}$ Ustawa z 25 lutego 1964 r., Kodeks rodzinny i opiekuńczy, t.jedn.: Dz. U. 2020, poz. 1359 (dalej jako: k.r.o.).

2 Tak Sokołowski (1982): 125. Por. uchwała SN z 8 marca 2006 r., III CZP 98/05, OSNC 2006, nr 10, poz. 158.

${ }^{3}$ Piasecki (2011); Sokołowski (2013).

${ }^{4}$ Do sytuacji podobnych, obligujących rodziców do wzmożonej opieki można zaliczyć inne niebezpieczeństwa zewnętrzne, takie jak pożar, powódź, ochrona przed osobami trzecimi, które mogłyby wyrządzić dziecku krzywdę (przykładowo przed złym towarzystwem, przed sektami itp.).

${ }^{5}$ Wyrok SA w Szczecinie z 6 czerwca 2019 r., III AUa 30/19, Lex nr 2692946.

${ }_{6}^{6}$ Tak Mazurkiewicz (2015): 309-312; Michałowska (2020): 259.

7 Jak podkreślił SN w postanowieniu z 24 listopada 2016 r. (II CA 1/16, OSNC 2017, nr 7/8, poz. 90): „nie ma definicji ustawowej zwrotu »dobro dziecka». Wypełnienie jego znaczenia powinno
} 
wują dziecko ${ }^{8}$ i wykonują pieczę nad jego osobą. Piecza obejmuje w szczególności kierowanie dzieckiem, zapewnienie dziecku odpowiednich warunków bytowych oraz to, co dla badanej tematyki jest szczególnie istotne, troskę o jego zdrowie i bezpieczeństwo ${ }^{9}$. Nie ulega wątpliwości, że każdy ze wskazanych obszarów władzy rodzicielskiej jest równie istotny, w związku z tym realizacja wszystkich obowiązków powinna być zapewniona w równej mierze. O ile należy zgodzić się z podkreślanym w literaturze stanowiskiem równości praw i obowiązków składających się na władzę rodzicielska i brakiem możliwości ich hierarchizowania przez rodziców ${ }^{10}$, o tyle rodzaj chronionych dóbr - zdrowie i bezpieczeństwo dziecka ujmowane w kategorii wartości szczególnych - wymagają zapewnienia ponadprzeciętnej ochrony. Wszelkie podejmowane przez rodziców działania oceniane sa przez pryzmat zasady dobra dziecka. W orzecznictwie podkreśla się, że wypełnienie znaczeniowe określenia „dobro dziecka” powinno być dokonywane w kontekście konkretnych okoliczności faktycznych, które odnoszą się do sytuacji, w jakiej znajduje się dziecko. Z uwagi na brak ustawowej definicji zwrotu „dobro dziecka” na szczególną uwagę zasługuję między innymi uprawnienie do ochrony życia i zdrowia oraz działań, które powinny zapewniać warunki do spokoju oraz prawidłowego, niezakłóconego rozwoju dziecka ${ }^{11}$. Wskazana ochrona powinna być realizowana zarówno w kontekście władzy rodzicielskiej, jak i w ramach ogólnych przepisów o ochronie dóbr osobistych (art. 23 k.c.) ${ }^{12}$. Jest tak dlatego, że będące dobrami osobistymi wartości, takie jak życie czy zdrowie, moga przejawiać się w różnych sferach, i podlegają ochronie, nie tylko jako pewne kategorie prawne, gdyż ochronie podlegają także wszystkie związane z określonymi dobrami uprawnienia ${ }^{13}$. Stąd realizowana w ramach pieczy nad osobą dziecka ochrona jego zdrowia oraz ochrona bezpieczeństwa mieszczą się we wskazanym zakresie uprawnień rodzicielskich.

być dokonywane w konkretnych okolicznościach faktycznych, zwłaszcza jeżeli wskazują na zaistnienie sytuacji, w jakiej znalazło się dziecko, wymagającej ingerencji ze strony innych podmiotów, w tym także sądu. Wyszczególnić należy uprawnienie do ochrony życia i zdrowia oraz wszelkich działań ze strony innych, które powinny zapewnić warunki do spokoju, prawidłowego, niezakłóconego rozwoju, poszanowania godności i udziału w procesie decydowania o jego sytuacji oraz zaznaczyć, że jest to zbiór niewyczerpany".

${ }^{8}$ W literaturze podkreśla się, że rodzice decydują o wszystkich sprawach związanych z osobą dziecka; tak Zieliński (2014): 193; Piasecki (2014).

9 Uchwała SN z 13 maja 2015 r., III CZP 19/15, OSNC 2016, nr 5, poz. 59.

10 Jędrejek (2017).

11 Postanowienie SN z 24 listopada 2016 r., II CA 1/16; por. Gajda (2006): 27.

12 Ustawa z 23 kwietnia 1964 r. - Kodeks cywilny, t.jedn.: Dz. U. 2020, poz. 1740 (dalej jako: k.c.). Treść art. 23 in fine wskazuje, na niezależność przewidzianej dla dóbr osobistych ochrony. Należy zwrócić uwagę, że podobnie jak w odniesieniu do jednakowego statusu wszystkich wchodzących w zakres władzy rodzicielskiej obowiązków, trudno jest klasyfikować dobra osobiste, które przykładowo wskazane w otwartym katalogu art. 23 k.c. podlegają jednakowej ochronie. Jest tak dlatego, że o ile zakres podmiotowy ochrony jest w k.r.o. jasno doprecyzowany, o tyle zakres przedmiotowy wskazanego obszaru pieczy nad osobą dziecka podlega dodatkowo ochronie ogólnej znajdującej swoje umocowanie właśnie w treści art. 23 k.c.

13 Piasecki (2003). 
Zawarty w pieczy nad osobą dziecka obowiązek ochrony jego zdrowia ${ }^{14}$ jest ujęty szeroko, a samo zdrowie rozumiane jest jako stan psychofizyczny, w jakim znajduje się dziecko. Co więcej, przyjmuje się, że nie chodzi tu o wyabstrahowane dobre zdrowie dziecka, a o jego aktualny stan zdrowia ${ }^{15}$. W literaturze podkreśla się, że zawarta w pieczy ochrona zdrowia dziecka obejmuje dbałość rodziców o stan tzw. dobrostanu zdrowotnego, odniesionego zarówno do sfery zdrowia fizycznego, jak i psychicznego, obejmuje m.in. konieczność podejmowania działań w zakresie profilaktyki zdrowotnej ${ }^{16}$. Stąd każde zagrożenie oraz każda ingerencja w zmianę tego stanu będą dawały podstawę do uruchomienia działań ochronnych, w tym przeciwdziałających zagrożeniu lub mających na celu usunięcie stanu naruszenia. W sytuacji gdy w rodzinie wychowuje się kilkoro dzieci, równie istotny jest stan zdrowia każdego z nich, a obowiązkiem rodziców jest jednakowa dbałość o zdrowie i bezpieczeństwo wszystkich dzieci. Dla dalszych badań szczególnie istotny jest rodzicielski obowiązek ochrony dziecka przed wspomnianym niebezpieczeństwem zewnętrznym, do którego niewątpliwie należy stan epidemii i związane z jej wystapieniem ryzyko dla zdrowia dziecka oraz członków jego rodziny ${ }^{17}$.

\section{BEZPIECZEŃSTWO ZDROWOTNE W SYTUACJI STANU EPIDEMII}

\section{Uzasadnienie wprowadzenia stanu epidemii}

W sytuacji szczególnego zagrożenia prawnie chronionych wartości, takich jak życie, zdrowie i bezpieczeństwo, konieczna może okazać się ich dodatkowa ochrona. Jej forma oraz zakres mogą dotyczyć określonej grupy osób lub ograniczonego obszaru, a w sytuacji gdy ryzyko związane z zagrożeniem bezpieczeństwa powszechnego jest duże, działania te powinny być skierowane do ogółu. Owa konieczność zintensyfikowania działań ochronnych w zależności od sytuacji może przybrać postać jednego ze stanów nadzwyczajnych ${ }^{18}$ bądź stanu epidemiii ${ }^{19}$. Podstawową przesłanką wprowadzenia stanu epidemii jest wystapienie na danym obszarze zakażeń lub zachorowań w liczbie, jaka

${ }^{14}$ Ich wyjątkowy charakter potwierdza fakt, że stanowiące podstawę roszczeń niemajątkowych prawa osobiste nie ulegają przedawnieniu.

15 Księżak (2014).

16 Tak Haberko (2020): 16-17.

17 Do sytuacji podobnych, obligujących rodziców do opieki można zaliczyć inne niebezpieczeństwa zewnętrzne, takie jak pożar, powódź, przed osobami trzecimi, które mogłyby wyrządzić dziecku krzywdę, przed złym towarzystwem, przed sektami itp.

18 Ustawa z 2 kwietnia 1997 r. Konstytucja Rzeczypospolitej Polskiej, Dz. U. 1997, Nr 78, poz. 483 ze zm.

${ }^{19} \mathrm{Na}$ potrzeby dalszych analiz przyjęto, że stan nadzwyczajny to szczególna sytuacja spowodowana nagłym, poważnym zagrożeniem bytu i funkcjonowania państwa o charakterze zewnętrznym lub wewnętrznym, który może przybrać postać: stanu wojennego, stanu wyjątkowego lub stanu klęski żywiołowej, a podstaw i przesłanek ich wprowadzenia należy poszukiwać w przepisach Konstytucji RP oraz w ustawie o stanie klęski żywiołowej, tak też Banaszak (2012): 1086. 
wcześniej nie występowała, stwarzających rzeczywiste zagrożenie zakażeniem $^{20}$. W sytuacji wystapienia epidemii podstawą wprowadzenia stan epidemii sa regulacje ustawy o zapobieganiu oraz zwalczaniu zakażeń i chorób zakaźnych u ludzi. To, co jest szczególnie istotne zarówno dla uzasadnienia wprowadzenia któregoś ze stanów nadzwyczajnych, jak i stanu epidemii, to wystapienie szczególnej sytuacji, do przezwyciężenia której nie są wystarczające zwykłe środki, czyli takie, które sa możliwe do skonstruowana na podstawie powszechnie obowiązujących i stosowanych na co dzień przepisów ${ }^{21}$. Aby podkreślony, ochronny cel mógł zostać osiagnięty, aby wartości podstawowe, w tym ochrona bezpieczeństwa (w szczególności bezpieczeństwa zdrowotnego), mogły być zapewnione, konieczne są ograniczenia niektórych praw i wolności ${ }^{22}$.

Pomijając kwestie prawidłowości jurydycznych podstaw wprowadzanych ograniczeń, aktualny stan prawny jest taki, że na mocy ustawy z 2 marca 2020 r. o szczególnych rozwiązaniach związanych z zapobieganiem, przeciwdziałaniem i zwalczaniem wirusa SARS-CoV2 ${ }^{23}$ kompetencje do wydania stosownego rozporządzenia przyznano Radzie Ministrów. W akcie tym wskazano zagrożony obszar wraz z uszczegółowieniem rodzaju strefy, na którym wystapił stan epidemii, jak również wskazano rodzaj stosowanych rozwiąań ${ }^{24}$. Uzasadnieniem wydania rozporządzenia jest, oprócz stanu epidemii lub stanu zagrożenia epidemicznego, charakter i rozmiar wskazanych zagrożeń, przekraczający możliwości działania podmiotów określonych w ustawie ${ }^{25}$, a ich zasadniczym celem jest ogólnie pojęta ochrona zdrowia publicznego ${ }^{26}$.

Ponadto w związku z rozporządzeniem Ministra Zdrowia z 20 marca 2020 r. w sprawie ogłoszenia na terytorium Rzeczypospolitej Polskiej stanu

20 Zgodnie z art. 2 pkt 9 ustawy z 5 grudnia 2008 r. o zapobieganiu oraz zwalczaniu zakażeń i chorób zakaźnych u ludzi, t.jedn.: Dz. U. 2019, poz. 1239: epidemia to występowanie na danym obszarze zakażeń lub zachorowań na chorobę zakaźną w liczbie wyraźnie większej niż we wcześniejszym okresie albo wystapienie zakażeń lub chorób zakaźnych dotychczas niewystępujących.

21 Por. Prokop (2005): 19.

22 Stan ten sprawia, że zwiększeniu ulegają kompetencji władzy wykonawczej oraz następuje uproszczenie procedur decyzyjnych, a nieprzestrzeganie adekwatnych do stanu przepisów wykonawczych obostrzone jest skutecznymi możliwościami ich egzekwowania. Z uwagi na obszar objęty zagrożeniem, gdy dotyczy ono województwa lub jego części, kompetencję do wprowadzenia epidemii przyznano odpowiednio wojewodzie na wniosek państwowego wojewódzkiego inspektora sanitarnego. W sytuacji gdy stan powyższy występuje na terenie więcej niż jednego województwa, kompetencję w tym zakresie ustawa przyznaje ministrowi właściwemu ds. zdrowia w porozumieniu z ministrem właściwym ds. administracji na wniosek Głównego Inspektora Sanitarnego. W obu przypadkach formą właściwą jest rozporządzenie uprawnionego podmiotu. Z uwagi na nagłość i wyjątkowość sytuacji powyższe rozporządzenia są niezwłocznie ogłaszane w dziennikach urzędowych i wchodzą w życie z dniem ich ogłoszenia.

${ }^{23}$ Ustawa z 2 marca 2020 r. o szczególnych rozwiązaniach związanych z zapobieganiem, przeciwdziałaniem i zwalczaniem COVID-19, innych chorób zakaźnych oraz wywołanych nimi sytuacji kryzysowych, Dz. U. 2020, poz. 374.

${ }^{24}$ Rozwiązania te mogą przybierać postać określonych ograniczeń, nakazów i zakazów na zagrożonym obszarze.

25 Tak art. 46.

${ }^{26}$ Ograniczenia te dotyczą m.in. czasowych uszczupleń zakresów działalności przedsiębiorców, czasową reglamentację zaopatrzenia w określonego rodzaju artykuły, obowiązek poddania się badaniom lekarskim, obowiązek poddania się kwarantannie, zakaz opuszczania strefy zero przez osoby chore i podejrzane o zachorowanie, nakazy lub zakazy przebywania w określonych miejscach. 
epidemii w związku z zakażeniami wirusem SARS-CoV-2 ${ }^{27}$ wskazane powyżej ograniczenia określone zostały również w rozporządzeniu Rady Ministrów z 29 maja 2020 r. w sprawie ustanowienie określonych ograniczeń, nakazów i zakazów w związku z wystapieniem stanu epidemii ${ }^{28}$. Zgodnie z $§ 1$ rozporządzenia z 20 marca 2020 r. wskazany został obszar, na którym wystapił stan epidemii wywołany zakażeniami wirusem SARS-CoV-2, a obszarem tym jest terytorium Rzeczypospolitej Polskiej.

Nie ulega wątpliwości, że podstawowym celem wprowadzenia stanu epidemii jest ochrona wartości podstawowych, a wszelkie działania powinny ku realizacji tego celu zmierzać. Niemniej działania te muszą uwzględniać szerszy niż jednostkowy czy grupowo określony interes oraz skutki ich wprowadzenia.

\section{Ochrona zdrowia i zapewnienie bezpieczeństwa zdrowotnego jako szczególny obowiązek władz publicznych w czasie stanu epidemii}

Przyjmujacc, że zdrowie to stan, w którym znajduje się organizm człowieka zarówno w obszarze fizycznym, jak i psychicznym, jest ono postrzegane w kategorii wartości - dobra osobistego, chronionej z uwagi na jej szczególny charakter $^{29}$. Konstytucja RP w art. 68 reguluje przyznane jednostce prawo do ochrony zdrowia, a z dualnej ochrony wynika, że z jednej strony stanowi ono prawo podmiotowe, z drugiej - jego ochrona należy do podstawowych obowiązków władz publicznych. W orzecznictwie TK prawo do ochrony zdrowia (prawo do zdrowia) stanowi podmiotowe prawo jednostki ${ }^{30} \mathrm{i}$ definiowane jest przez pryzmat jego powiązań z innymi prawami podstawowymi, w szczególności z ochroną życia i godności ${ }^{31}$. Tak ujęte wymaga zapewnienia szczególnej ochrony oraz stworzenia realnych warunków do zapewnienia możliwości jego realizacji ${ }^{32}$. Warto podkreślić, że w dywagacjach na temat istoty prawa do ochrony zdrowia, ujmowanego jako norma programowa, przyjmuje się założe-

${ }^{27}$ Rozporządzenie Ministra Zdrowia z 20 marca 2020 r. w sprawie ogłoszenia na terytorium Rzeczypospolitej Polskiej stanu epidemii, Dz. U. 2020, poz. 491.

${ }_{28}$ Rozporządzenie Rady Ministrów z 29 maja 2020 r. w sprawie ustanowienie określonych ograniczeń, nakazów i zakazów w związku z wystapieniem stanu epidemii, Dz. U. 2020, poz. 964.

${ }^{29} \mathrm{SN}$ zwraca uwagę, że działanie godzące w bezpieczeństwo zdrowotne, powodujące obawę o stan zdrowia, jest działaniem zagrażajacym zdrowiu (wyrok SN z 9 maja 2007 r., II CSK 42/07, Lex nr 393861).

30 Prawo to jest postrzegane jako sfera możności postępowania w określony sposób, przyznana przez normę prawną w celu ochrony interesu uprawnionego podmiotu; Wolter, Ignatowicz, Stefaniuk (2001): 128-129. Przy czym w doktrynie nie ma zgodności co do charakteru art. 68 Konstytucji RP. Podkreśla się, że obok statuowanego w ust. 1 prawa do ochrony zdrowia, traktowanego w kategorii prawa podmiotowego, reszta artykułu ma raczej charakter normy programowej, tak Garlicki, Zubik (2016).

${ }^{31}$ Wyroki TK: z 7 stycznia 2004 r., K 14/03, OTK-A 2004, nr 1, poz. 1; z 30 września 2008 r., K44/07, OTK-A 2008, nr 7, poz. 126; wyrok WSA w Warszawie z 21 marca 2019 r., VII SA/Wa 2676/18, Lex nr 2657868; wyrok WSA w Warszawie z 10 grudnia 2019 r., VII SA/Wa1743/19, Lex nr 2799439.

${ }^{32}$ Garlicki, Zubik (2016). 
nie pewnego minimalnego poziomu ochrony wyznaczonego przez jego istotę $e^{33}$. Zatem sytuacji gdy regulacja szczegółowa spowoduje ingerencję w prawo do ochrony zdrowia, nie zapewniając owego minimum, z uwagi na charakter tego prawa, mimo że niedopuszczalne będzie wysuwanie przez podmiot roszczeń o charakterze pozytywnym, jego istota uwypukli się w kontekście negatywnych obowiązków ustawodawcy. Jak podkreślił TK w wyroku z 24 października 2000 r.: „polegać będzie na wskazaniu ustawodawcy pewnych minimalnych obowiązków, powodując, że dane prawo zostanie wydrążone z rzeczywistej treści, powodujacc, że naruszona zostanie jego istota. Wówczas możliwym jest postawienie takiej regulacji zarzutu niekonstytucyjności”34.

W związku z takim ujęciem istoty zagadnienia ochrony zdrowia w jego treści wyodrębnić można z jednej strony gwarantowane jednostce aktywne działania służące zapobieganiu i zwalczaniu chorób, z drugiej - obowiązek podejmowania przez władze publiczne działań służących jego ochronie i realizacji ${ }^{35}$. Stan ten odnosi się do zróżnicowanych sytuacji, a jedną z nich jest konieczność ochrony zdrowia uczęszczających do szkół dzieci. Ten dualny - konstytucyjny i kodeksowy - zakres ochrony zdrowia szczególnie wybrzmiewa w kontekście problemu naruszenia bezpieczeństwa zdrowotnego. Może ono bowiem powodować lęk o stan zdrowia własnego lub innych osób, w tym osób najbliższych, i stanowi w istocie zagrożenie dobra osobistego, jakim jest samo zdrowie ${ }^{36}$. Należy więc zadać pytanie, jak w sytuacji stanu epidemii oceniać realizację obowiązku nauki pod kątem ochrony wartości podstawowych, którymi są ochrona zdrowia i bezpieczeństwa realizujących ten obowiązek dzieci.

\section{BEZPIECZEŃSTWO ZDROWOTNE DZIECI A REALIZACJA OBOWIĄZKU NAUKI W SYTUACJI STANU EPIDEMII}

Intelektualny i emocjonalny rozwój dziecka, gwarantowany w krajowym oraz międzynarodowym porządku prawnym ${ }^{37}$, realizuje się w przyznanym każdemu dziecku prawu do nauki oraz zintegrowanym z nim obowiązku

${ }_{33}$ Podkreślić należy, że obok statuowanego w ust. 1 prawa do ochrony zdrowia, traktowanego w kategorii prawa podmiotowego, reszta artykułu ma raczej charakter normy programowej; tak Banaszak (2012): 408-413; Garlicki, Zubik (2016).

${ }^{34}$ Wyrok TK z 24 października 2000 r., K 12/00, OTK 2000/7/255, mimo że odniesiony do art. 66 Konstytucji, zachowuje swoją aktualność do innych praw. Zdaniem TK uznanie niekonstytucyjności ustawy jest możliwe tylko wtedy, gdy zostaną przedstawione argumenty w sposób niewątpliwy wykazujące, że kwestionowana regulacja ustawowa prowadzi do naruszenia ,istoty” danego prawa, w szczególności przez wydrążenie tego prawa z jego rzeczywistej treści.

${ }_{35}$ Por. wyroki TK: z 24 lutego 2004 r., 54/02, OTK-A 2004, nr 2, poz. 10; z 23 marca 1999 r., K 2/98, OTK 1999, nr 3, poz. 38; postanowienie TK z 15 stycznia 2013 r., SK 21/12, OTK-A 2013, nr 1 , poz. 1 .

36 Wyrok SN z 9 maja 2007 r., II CSK 42/07, Lex nr 393861.

37 Por. art. 28 Konwencji o prawach dziecka, Dz. U. 1991, Nr 120, 526; art 3 ustawy z 6 stycznia 2000 r. o Rzeczniku Praw Dziecka, t.jedn.: Dz. U. 2020, poz. 141. 
nauki. Jego istota zawarta jest $\mathrm{w}$ dualnej budowie art. 70 Konstytucji RP, w którym wskazane prawo i obowiązek przenikają się wzajemnie. Treścią obowiązu nauki jest uczestniczenie każdego podlegającego prawu RP dziecka do ukończenia przez nie 18 roku życia w zajęciach szkolnych, w zakresie i czasie przewidzianym prawem. Istota konstytucyjnie gwarantowanego prawa do nauki, postrzeganego w kategoriach zarówno wartości indywidualnej, jak i społecznej, jest możliwość dalszej nauki po zakończeniu jej obowiązkowego etapu, w tym wyboru formy, sposobu i zakresu jej kontynuowania ${ }^{38}$. Szczegółowe zasady realizacji obowiązku nauki zawarte zostały w ustawie z 14 grudnia 2016 r. - Prawo oświatowe ${ }^{39}$, a jednym ze celów wskazanych w przepisach ogólnych jest utrzymywanie bezpiecznych i higienicznych warunków nauki, wychowania i opieki w szkołach i placówkach tworzących system oświaty (art. 1 pkt 14 u.p.o.). Obowiązek nauki realizowany jest w ramach funkcjonującego w Polsce systemu oświaty, tworzącego skoordynowany układ podmiotowo-przedmiotowy oraz poprzez obowiązujące w nim reguły porządkujące ${ }^{40}$.

Zgodnie z art. 40 ust. 1 u.p.o. na rodziców dziecka podlegającego obowiązkowi nauki (tzw. obowiązkowi szkolnemu) nałożone zostały określone wymogi, w tym obowiązek dopełnienia czynności związanych ze zgłoszeniem dziecka do szkoły oraz zapewnienia regularnego uczęszczania dziecka na zajęcia szkolne. Pomijając rozważania na temat oczywistego celu tych obowiązków, ich realizacja podlega kontroli, która we wskazanym zakresie przeprowadzają dyrektorzy szkół ${ }^{41}$. Za niedopełnienie ustawowo wskazanych obowiązków uznaje się między innymi sytuację nieuczęszczania dziecka na zajęcia szkolne (art. 42 ust. 2 u.p.o.). Ustawa określa ten stan jako nieusprawiedliwiona nieobecność, która zaistnieje w sytuacji, gdy nieobecność przekroczy połowę czasu nauki w danym miesiącu. Administracyjnoprawną konsekwencja, która zagraża w takiej sytuacji, jest możliwość nałożenia na rodziców (opiekunów) kary grzywny.

Dla prawidłowości procesu nauki konieczne są odpowiednie warunki jego realizacji, a ustawowo ukształtowana struktura systemu oświaty wskazuje i wyodrębnia odpowiedzialne za ten proces tzw. organy prowadzące, przypisując im tym samym określone obowiązki. W związku z tym organ prowadzący szkołę lub placówkę odpowiada za jej działalność, a do jego zadań należy w szczególności zapewnienie warunków działania szkoły lub placówki, w tym bezpiecznych i higienicznych warunków nauki, wychowania i opieki. Spełnienie tego obowiązku oznacza konieczność zapewnienia pewnego minimum, na co podstawowy wpływ mają warunki, w jakich funkcjonuje placówka, w tym jej liczebność oraz sposób i zakres finansowania. Mimo oczywistej różnorodności placówek edukacyjnych zasadniczym celem regulacji ustawowej jest za-

${ }^{38}$ Garlicki, Zubik (2016); Banaszak (2012): 416-418.

39 Ustawa z 14 grudnia 2016 r. - Prawo oświatowe, t.jedn.: Dz. U. 2020, poz. 910 ze zm. (dalej jako: u.p.o.).

40 Pilich (2018).

${ }^{41} \mathrm{~W}$ odniesieniu natomiast do szkół ponadpodstawowych kontrola spoczywa na gminach (art. 41 ust. 1 u.p.o.). 
pewnienie pewnego standardu warunków bezpieczeństwa realizacji obowiązku szkolnego rozumianego jako pewne minimum.

W sytuacjach szczególnych, takich jak stan epidemii, wskazany w ustawie obowiąek zapewnienia odpowiednich bezpiecznych i higienicznych warunków nauki nabiera szczególnego znaczenia. Aktualna sytuacja stanu epidemii sprawiła, że na podstawie art. 10 ust. 1 pkt 1 i art. 68 ust. 1 pkt 6 u.p.o. opracowane zostały wytyczne i zalecenia ${ }^{42}$ dla publicznych i niepublicznych placówek wchodzących w system oświaty. Wskazały one zakres dodatkowych obowiąków nałożonych na dyrektorów szkół i placówek oraz procedury postępowania $\mathrm{w}$ sytuacjach w nich wskazanych. W założeniu ich podstawowym celem jest zapewnienie bezpieczeństwa i ochrony zdrowia zarówno uczęszczających do szkoły dzieci, jak i pracowników szkół.

Niestety porównanie zawartych w rozporządzeniu regulacji w zakresie wymogów bezpieczeństwa realizacji obowiązku szkolnego w sytuacji stanu epidemii, w tym wytycznych i zaleceń, w zderzeniu z rzeczywistościa jednoznacznie wskazuje, że w większości placówek nie ma warunków ani perspektyw ich realizacji. Większa część szkół nie ma możliwości zmiany organizacji form nauczania, tzn. godzin rozpoczęcia zajęć, izolowania uczniów w poszczególnych grupach czy zachowania wskazanych w zaleceniach bezpiecznych odległości. Niedostatki w warunkach lokalowych, kadrowych i infrastrukturze szkolnej uczyniły zalecenia niewykonalnymi. W efekcie spowodowały, że konstytucyjna gwarancja ochrony zdrowia oraz ustawowy wymóg bezpiecznych i higienicznych warunków nauki nie są możliwe do realizacji. Dynamika sytuacji epidemicznej ${ }^{43}$, w tym powracajacych co pewien czas decyzji o powrocie do stacjonarnego systemu nauki ${ }^{44}$, uzasadnia poszukiwanie odpowiedzi na pytanie o prawne podstawy ingerencji rodziców w realizację obowiązku szkolnego ${ }^{45}$. W uszczegółowieniu dotyczące zarówno podstaw rodzicielskiej ingerencji, jak i gwarancji ochrony dobra dziecka oraz dobra jego rodziny.

${ }^{42}$ Wytyczne z 5 sierpnia 2020 r. Ministra Edukacji Narodowej, Ministra Zdrowia i Głównego Inspektora Sanitarnego dla publicznych i niepublicznych szkół i placówek od 1 września 2020 r., wydane na podstawie art. 8a ust. 5 pkt 2 ustawy z 14 marca 1985 r. o Państwowej Inspekcji Sanitarnej, Dz. U. 2019, poz. 59 ze zm.; zalecenia z 12 sierpnia 2020 r. wydane przez Ministra Edukacji Narodowej i Głównego Inspektora Sanitarnego dla dyrektorów publicznych i niepublicznych szkół i placówek w strefie czerwonej/żółtej, wydane na podstawie art. 8a ust. 5 pkt 2 o Państwowej Inspekcji Sanitarnej.

43 Rozporządzenie Ministra Edukacji Narodowej z 12 sierpnia 2020 r. w sprawie czasowego ograniczenie funkcjonowania jednostek systemu oświaty w związku z zapobieganiem, przeciwdziałaniem i zwalczaniem COVID-19, Dz. U. 2020, poz. 1389 (w wersji z 9 listopada 2020). Kolejne zmiany w ww. rozporządzeniu wchodziły: 16 października (Dz. U. 2020, poz.1830), 21 października (Dz. U. 2020, poz. 1859) i 24 października (Dz. U. 2020, poz. 1870). Wszystkie dotyczyły decyzji o zmianach formy prowadzenia zajęć w szkołach oraz o sukcesywnym zamykaniu jednostek systemu oświaty.

${ }_{44}$ Sytuacja taka dotyczyła klas 1-3 szkół podstawowych od 25 maja 2020, w odniesieniu do wszystkich szkół - od 1 września 2020 r.

45 Jadach (2020): 59-60. 


\section{BEZPIECZEŃSTWO ZDROWOTNE DZIECKA I JEGO RODZINY VS OBOWIĄZEK NAUKI W SYTUACJI STANU EPIDEMII}

Szczególna sytuacja stanu epidemii, liczne niewiadome dotyczące sposobów rozprzestrzeniania się wirusa SARS-CoV-2, obawa zakażenia i ciężkiego przebiegu choroby COVID-19, w szczególności w grupie osób o osłabionej odporności spowodowanej innymi schorzeniami oraz w grupie osób w podeszłym wieku, spowodowały zaistnienie stanu niepewności. Nakładająca się na tę skomplikowaną sytuację dynamika decyzyjna co do form realizacji obowiązku szkolnego oraz zmienność ustaleń, nie zawsze znajdujących racjonalne uzasadnienie, spowodowały liczne i uzasadnione obawy co do bezpieczeństwa dzieci i ich rodzin ${ }^{46}$.

Nie ulega wątpliwości, że obowiązek nauki realizowany w zwykłych i bezpiecznych warunkach jest zbieżny $\mathrm{z}$ dobrem dziecka i jako taki daje pełne podstawy do jego egzekwowania w ustawowo określony sposób. Niemniej jego realizacja i egzekwowanie w warunkach szczególnych, do jakich należy stan epidemii, budzi poważne i - jak wykazano - uzasadnione wątpliwości. Nie powinny więc dziwić obawy rodziców, będące z jednej strony wyrazem troski o bezpieczeństwo i zdrowie dzieci, z drugiej - realizacją kodeksowego obowiązku ocenianego przez pryzmat zasady dobra dziecka ${ }^{47}$. Uzasadniony w związku z tym jest niepokój rodziców nie tylko pod kątem bezpieczeństwa oraz ochrony zdrowia dziecka, ale ewentualnej oceny staranności wykonywania przez nich pieczy nad nim. Trudno w tej szczególnej sytuacji wymagać od rodziców prawidłowego i miarowego sprawowania pieczy nad osobą dziecka ${ }^{48}$, gdy pozbawia się ich realnych możliwości decydowania o sposobie jej realizacji.

Idąc o krok dalej, obawy o zdrowie i bezpieczeństwo dziecka odnoszą się również do innych zamieszkujących wspólnie z dzieckiem członków rodziny. Stosując analogię do ocenianej pod kątem zasady dobra dziecka postawy jego rodziców, uzasadnione jest w kontekście oceny bezpieczeństwa zdrowotnego rodziny dziecka odwołanie się do klauzuli generalnej dobra rodziny ${ }^{49}$, pełniącej funkcję zasady prawnej miarodajnej dla całego prawa cywilnego ${ }^{50}$. Mimo braku definicji pojęcia dobra rodziny, na podstawie treści art. 71 ust 1 Konstytucji RP, doktryna i orzecznictwo podkreślają potrzebę szerokiego jej ujęcia, akcentując aspekt materialnego, duchowego, a także moralnego istnienia i funkcjonowania rodzi$n^{51}$. Przyjmując, że bez względu na sposób pojmowania rodziny ${ }^{52}$, niezależnie

${ }^{46}$ Ryzyko zakażenia dotyczy również pracowników szkoły.

47 Powoływano się na uzasadnienie postanowienia SN z 12 grudnia 2000 r., V CKN 1751/00, Lex nr 1635378, w którym podkreślono, że stosunki między rodzicami a dziećmi pozostającymi pod ich władzą rodzicielską mają szczególny charakter w tym znaczeniu, że o stopniu staranności rodziców przy jej wykonywaniu decyduje dobro dziecka.

${ }^{48}$ Wyrok SN z 2 grudnia 1957 r., I CR 1045/56, OSN 1959, nr 3, poz. 76.

${ }^{49}$ Sokołowski (1987): 11.

${ }^{50}$ Radwański (1981): 24-25.

${ }^{51}$ Banaszak (2012): 423-425; Grzejdziak (2002): 467-468.

${ }^{52} \mathrm{Na}$ potrzeby niniejszej analizy i z uwagi na szerszy kontekst prowadzonych badań przyjęto, że rodzina jest postrzegana jako grupa, por. Tyszka (2002): 137; Michałowska (2017): 121-124. 
od typu rodziny ${ }^{53}$, jej formy, składu osobowego czy różnorodności - do obowiąku władz publicznych należy zapewnienie jej należytego stopnia ochrony, ochrona ta powinna dotyczyć zarówno rodziny jako całości, jak i poszczególnych jej członków. Statuowany w doktrynie szeroki sposób ujęcia dobra rodziny, obostrzony zakresem art. 18 Konstytucji RP wyznaczającym wartości o priorytetowym znaczeniu, wymaga zapewnienia rodzinie odpowiedniego poziomu opieki, w tym zapewnienia jej bezpieczeństwa zdrowotnego $0^{54}$. Tak ujęty kształtuje kodeksowa zasadę ochrony rodziny, a jej zakres wymaga uwzględnienia dwóch aspektów: zewnętrznego i wewnętrznego. Pierwszy odnosi się do podejmowanych przez organy publiczne działań skierowanych do rodziny, drugi - do sytuacji prawnej członków rodziny obowiązanych do dbałości o jej dobro ${ }^{55}$.

W związku z tym istotna w kontekście badanego zagadnienia rola obu klauzul (dobra dziecka i dobra rodziny) skłania do pytania o ich wzajemną relację. Problem ten został dostrzeżony przez Sąd Najwyższy w latach siedemdziesiątych XX w. w zaleceniach kierunkowych z 9 czerwca 1976 r. i mimo upływu czasu nadal zachowuje swoją aktualność. Zdaniem SN: „przyjęta w prawie rodzinnym zasada dobra dziecka rozstrzyga przede wszystkim o tym, jak jego rodzice i opiekunowie powinni wykonywać swe obowiązki względem dzieci i rodziny oraz w jakim kierunku powinny iść rozstrzygnięcia sądu w sprawach rodzinnych" ${ }^{56}$. W związku z tym, jak słusznie podkreśla Anna Sylwestrzak, pojęcie dobra rodziny i dobra dziecka należy uznać za spójne i jednokierunkowe, a wynikające $\mathrm{z}$ nich dyrektywy za zbieżne $\mathrm{z}$ dostrzegalnym zakresem działania obu klauzul ${ }^{57}$. W związku z tym należy przyjać, że przepis art. 71 Konstytucji RP określa jedynie cele państwa, a o jego rozumieniu w konkretnej sytuacji decyduje ustawodawca, co oczywiście nie oznacza pełnej swobody decyzyjnej ${ }^{58}$. Skoro zadaniem państwa jest uwzględnianie dobra rodziny, to użyte określenie „uwzględniania” oznacza między innymi badanie skutków projektowanych regulacji prawnych pod katem dobra rodziny ${ }^{59}$.

Odnosząc poczynione uwagi do oceny formy obowiązku nauki w sytuacji stanu epidemii, należy stwierdzić, że w kontekście obu klauzul generalnych rozwiązania legislacyjne nakładajace obowiązek nauki w trybie stacjonarnym, które obowiązywały w maju i w czerwcu oraz od września do października roku 2020 i które w podobnej formie powróciły na początku $2021^{60}$, nie uwzględniały

Zasada dobra rodziny odnosi się w równej mierze do rodziny małej oraz do rodziny wielkiej, wielopokoleniowej; por. Sylwestrzak (2019): 485.

${ }^{53}$ Michałowska (2017): 137-139.

${ }^{54}$ Banaszak (2012): 423-425.

${ }^{55}$ Sylwestrzak (2019): 318. Por. wyrok TK z 18 listopada 2014 r., SK 7/11, Lex nr 1544151, w którym podkreślono, że w pojęciu „dobro rodziny” zawiera się przede wszystkim „jej trwałość, która tworzy podstawy poczucia bezpieczeństwa wszystkich jej członków, a zwłaszcza tych najsłabszych - dzieci, osób chorych lub niepełnosprawnych”.

${ }^{56}$ Tak też Stojanowska (1999): 91.

57 Sylwestrzak (2019): 322.

${ }^{58}$ Banaszak (2012): 423-425.

${ }^{59}$ Haczkowska (2014).

${ }^{60}$ Obowiązek nauki stacjonarnej dotyczący dzieci klas 1-3 szkół podstawowych, rozporządzenie Ministra Edukacji i Nauki z 28 stycznia 2021 r. zmieniające rozporządzenie w sprawie 
ani dobra rodziny, ani dobra dziecka. Nie zapewniły bowiem bezpieczeństwa realizującym obowiązek nauki dzieciom, nie dały podstaw do realizacji rodzicielskiej troski o zdrowie dziecka i godziły bezpośrednio w zasadę ochrony jego dobra. W kontekście klauzuli dobra rodziny nie uwzględniły sytuacji rodzinno-zdrowotnej dziecka, gdy stan zdrowotny lub wiek któregoś z członków mieszkającej pod wspólnym dachem rodziny tego wymagał. W związku z tym oczekiwanie w takiej sytuacji realizacji obowiązku nauki niosącego realne ryzyko dla zdrowia i bezpieczeństwa stanowi naruszenie zarówno zasady dobra dziecka, jak i dobra rodziny. Co więcej, stanowi ingerencję w prawa podmiotowe samego dziecka, a także wykonujących władzę rodzicielską rodziców. Jak podkreślono, godzi również w konstytucyjną ochronę zdrowia. Pośrednim rozwiązaniem mogłoby być tzw. nauczanie domowe, realizowane w trybie art. 37 u.p.o. Jego istota sprowadza się do odbywania zajęć w warunkach domowych, ale bez udziału nauczyciela, gdyż wiedza przekazywana jest najczęściej przez rodziców. Już samo to wskazuje, że nie każde z rodziców ma ku temu odpowiednie kompetencje bądź możliwości czasowe (np. z uwagi na konieczność wykonywania pracy zawodowej, czy konieczność sprawowania opieki nad pozostałymi dziećmi). Ponadto uznaniowość wdrożenia tej formy nauki oraz sposób weryfikowania wiedzy oraz kwestie finansowania stanowią istotne przeszkody w jej stosowaniu $^{61}$. Nie rozwiązują również badanego problemu.

\section{PODSUMOWANIE}

Będące przedmiotem rozważań zagadnienia ochrony bezpieczeństwa zdrowotnego dziecka i jego rodziny w sytuacji stanu epidemii, badane pod katem realizacji obowiązku szkolnego, nasuwają szereg wniosków. Po pierwsze, sprawujący pieczę nad osobą dziecka rodzice mają obowiązek zapewnienia dziec$\mathrm{ku}$ bezpieczeństwa, w tym bezpieczeństwa zdrowotnego oraz ochrony przed zagrożeniami. Jednym z zagrożeń jest niewątpliwie stan epidemii, a związane $\mathrm{z}$ nią obawy rodziców znajduja uzasadnienie nie tylko w wyjątkowości sytuacji, ale przede wszystkim ryzyku związanym z rozprzestrzenieniem się zakażenia oraz wątpliwościami co do wiarygodności danych statystycznych dotyczących skali zachorowań. Wszelkie bowiem godzące w bezpieczeństwo zdrowotne działania moga powodować uzasadnione lęki i obawy o stan zdrowia, godząc jednocześnie w kategoryzowane w wartościach szczególnych zdrowie. Stan ten niewątpliwie uzasadnia obawy rodziców sprawujących pieczę na osoba dziecka.

Po drugie wskazana sytuacja skłoniła do postawienia pytania o wzajemna relację wynikającego z pieczy nad osobą dziecka, obowiązku ochrony jego zdrowia i bezpieczeństwa w relacji do obowiązku nauki. Nie ulega wątpliwo-

\footnotetext{
czasowego ograniczenia funkcjonowania jednostek systemu oświaty w związku z zapobieganiem, przeciwdziałaniem i zwalczaniem COVID-19, Dz. U. 2021, poz. 202.

61 Jadach (2020): 51-53.
} 
ści, że nauka i uczęszczanie do szkoły są zbieżne z dobrem dziecka, a potrzeba jego socjalizacji, bezpośrednich kontaktów z rówieśnikami stanowi określona wartość. Paradoks polega jednak na tym, że w sytuacji stanu epidemii spowodowanej wirusem SARS-CoV2, który jest nowy, niezbadany i mało przewidywalny, głównym źródłem zakażenia są właśnie bezpośrednie kontakty. W związku z tym realizacja obowiązku nauki w formie stacjonarnej powoduje bezpośrednie zagrożenie dla zdrowia i bezpieczeństwa dziecka i jego rodziny. Sprawujący pieczę nad osobą dziecka rodzice, obowiązani do dbałości o jego zdrowie i bezpieczeństwo, w ramach przysługującej im autonomii mają prawo zaingerować w realizację obowiązku nauki, gdy warunki, w jakich obowiązek ten jest realizowany, nie zapewniają bezpieczeństwa.

Po trzecie, należy podkreślić, że podmiotem ochrony jest dziecko i jego dobro, w związku z tym podejmowane w tym obszarze działania muszą być oceniane w kontekście zasady dobra dziecka. Zatem niespełniające reżimu sanitarnego warunki realizacji obowiązku szkolnego pozostają z zasadą dobra dziecka w sprzeczności. Co więcej, trudno znaleźć uzasadnienie takiego rozwiązania prawnego, które wymaga od rodziców akceptacji realizacji obowiązku nauki w zagrażajacych zdrowiu dziecka warunkach.

Po czwarte, zwrócono uwagę, że ryzykowne warunki realizacji obowiąku szkolnego mogą stanowić realne zagrożenie nie tylko dla zdrowia dziecka, lecz także członków jego rodziny. Złożoność badanego problemu wymagała oceny analizowanego problemu w kontekście klauzuli generalnej dobra rodziny oraz jej relacji z zasadą dobra dziecka. Wyniki prowadzonych badań potwierdziły spójność i uzupełnianie się obu zasad. Odnosząc poczynione uwagi do oceny formy obowiązku nauki w sytuacji stanu epidemii, należy stwierdzić, że w kontekście obu klauzul generalnych aktualne rozwiązania legislacyjne nie uwzględniły ani dobra rodziny, ani dobra dziecka. Nie zapewniły bezpieczeństwa realizującym obowiązek nauki dzieciom, nie dały podstaw do realizacji rodzicielskiej troski o zdrowie dziecka i godziły bezpośrednio w zasadę ochrony jego dobra. W kontekście samej zasady dobra rodziny nie uwzględniły ponadto sytuacji rodzinno-zdrowotnej dziecka, gdy stan zdrowotny lub wiek któregoś z członków mieszkającej pod wspólnym dachem rodziny dziecka tego wymaga. Oczekiwanie w takiej sytuacji realizacji obowiąku nauki niosacego realne ryzyko dla zdrowia i bezpieczeństwa stanowi naruszenie zarówno zasady dobra dziecka, jak i dobra rodziny. Co więcej, stanowi ingerencję w prawa podmiotowe zarówno samego dziecka, jak i wykonujących władzę rodzicielską rodziców. Jak podkreślono, godzi również w konstytucyjnie zapewnioną ochronę zdrowia.

De lege ferenda w sytuacji stanu epidemii należy zaproponować uelastycznienie rozwiązań dotyczących form nauki i konieczności ich dostosowania do sytuacji zdrowotnej i rodzinnej dziecka. W związku z tym w okresach, gdy obowiązek szkolny realizowany jest w trybie stacjonarnym, prowadzone lekcje powinny być transmitowane online. Zaproponowane rozwiązanie nie ogranicza autonomii decyzyjnej rodziców, pozwala na realizację obowiązku szkolnego i zapewnia większe bezpieczeństwo zdrowotne dziecka i jego rodziny. W ogólnym zarysie techniczna strona jego realizacji wymaga jedynie zapewnienia sprzętu do transmitowania lekcji, aby prowadzona stacjonarnie lekcja 
była jednocześnie dostępna dla tych uczniów, których sytuacja zdrowotna lub rodzinna uzasadnia czasowa realizuję obowiązku szkolnego $\mathrm{w}$ formie zdalnej. Rozwiązanie to pozostaje $\mathrm{w}$ zgodności $\mathrm{z}$ ogólnymi zasadami ochronnymi odniesionymi do zdrowia, bezpieczeństwa, dobra dziecka oraz dobra rodziny. Pozwala rodzicom świadomie realizować wynikające z pieczy nad osobą dziecka obowiązki odniesione do ochrony jego zdrowia i bezpieczeństwa. Nie zmusza rodziców do wykorzystywania przeznaczonej do realizacji innych celów formy edukacji domowej, której nieumiejętne prowadzenie nie przyniesie oczekiwanych efektów edukacyjnych. Pozostaje też w zgodności z konstytucyjnie i konwencyjnie gwarantowanym prawem do nauki.

Banaszak, B. (2012). Konstytucja Rzeczypospolitej Polskiej. Komentarz. Wyd. 2. Warszawa.

Gajda, J. (2006). Przesłanka dobra dziecka przy ustalaniu jego pochodzenia. Państwo i Prawo 61(1): 24-43.

Grzejdziak, A. (2002). Prawo do wychowania dziecka w rodzinie, [w:] B. Banaszak, A. Preisner (red.), Prawa i wolności obywatelskie w Konstytucji RP. Warszawa: 478-491.

Haberko, J. (2020). Prawnomedyczne relacje rodzice - dziecko - państwo, [w:] M. Łączkowska-Porawska (red.), Dziecko - rodzice - państwo w kontekście świadczeń zdrowotnych, edukacyjnych i przemocy domowej. Warszawa: $13-38$.

Haczkowska, M. (2014). Konstytucja Rzeczypospolitej Polskiej. Komentarz. Warszawa: Lex. el.

Jędrejek, G. (2017). Kodeks rodzinny i opiekuńczy. Komentarz. Warszawa: Lex el.

Jadach, K. (2020). Oświatowe konteksty wykonywania pieczy nad małoletnim, [w:] M. Łączkowska-Porawska (red.), Dziecko - rodzice - państwo w kontekście świadczeń zdrowotnych, edukacyjnych i przemocy domowej. Warszawa: 47-88.

Księżak, P. (2014). Komentarz do art. 23 pkt 5, [w:] P. Księżak, M. Pyziak-Szafnicka (red.), Kodeks cywilny. Komentarz. Część ogólna. Wyd. 2. Warszawa: Lex el.

Mazurkiewicz, J. (2015). Rodzinne do remontu! Czyli o potrzebie wielkiej reformy prawa rodzinnego, [w:] P. Stec, M. Załucki (red.), 50 lat kodeksu cywilnego. Perspektywy rekodyfikacji. Warszawa: 301-332.

Michałowska, K. (2017). Niemajątkowe wartości życia rodzinnego w Polskim prawie cywilnym. Warszawa.

Michałowska, K. (2020). Rodzicielstwo i rodzicielskie prawa podmiotowe w obliczu human enhancement - zagadnienia wybrane, [w:] J. Pisuliński, J. Zawadzka (red.), Aksjologia prawa cywilnego i cywilnoprawna ochrona dóbr. Warszawa: 253-264.

Piasecki, K. (2003). Komentarz do art. 23 pkt 5, [w:] K. Piasecki (red.), Kodeks cywilny. Księga pierwsza. Część ogólna. Komentarz. Warszawa: Lex el.

Piasecki, K. (2011). Komentarz do art. 96 pkt 5, [w:] K. Piasecki (red.), Kodeks rodzinny i opiekuńczy. Komentarz. Wyd. 5. Lex el.

Piasecki, K. (2014). Komentarz do art. 95 pkt 4, [w:] K. Piasecki (red.), Kodeks cywilny. Komentarz. Lex el.

Pilich, M. (2018). Komentarz do ustawy - Prawo oświatowe, [w:] Prawo oświatowe oraz przepisy wprowadzajace. WPK. Lex el.

Prokop, K. (2005). Stany nadzwyczajne w Konstytucji Rzeczypospolitej Polskiej z dnia 2 kwietnia 1997 r. Białystok.

Radwański, Z. (1981). Pojęcie i funkcje „dobra dziecka” w polskim prawie rodzinnym i opiekuńczym. Studia Cywilistyczne 31: 3-32.

Sokołowski, T. (1982). Charakter prawny władzy rodzicielskiej. Ruch Prawniczy, Ekonomiczny i Socjologiczny 46(3): 123-134.

Sokołowski, T. (1987). Władza rodzicielska nad dorastającym dzieckiem. Poznań.

Sokołowski, T. (2013). Komentarz do art. 95, [w:] H. Dolecki, T. Sokołowski (red.), Kodeks rodzinny i opiekuńczy. Komentarz. Wyd. 2. Warszawa: Lex el. 
Stojanowska, W. (1999). Dobro dziecka jako instrument wykładni norm konwencji o prawach dziecka oraz prawa polskiego i jako dyrektywa jego stosowania, [w:] T. Smyczyński (red.), Konwencja o prawach dziecka. Analiza i wykładnia. Poznań: 81-109.

Sylwestrzak, A. (2019a). O klauzuli generalnej dobra rodziny. Studia Prawnoustrojowe 45: 313324.

Sylwestrzak, A. (2019b). Skutki prawne przynależności krewnych do tzw. wielkiej rodziny. Gdańskie Studia Prawnicze 2: 483-498.

Tyszka, Z. (2002). Rodzina we współczesnym świecie. Poznań.

Wolter, A., Ignatowicz, J., Stefaniuk, K. (2001). Prawo cywilne. Zarys części ogólnej. Wyd. 2. Warszawa.

Zieliński, A. (2014). Prawo rodzinne. Warszawa.

\section{PROTECTION OF THE HEALTH OF A CHILD AND ITS FAMILY AND THE IMPLEMENTATION OF THE OBLIGATION TO LEARN IN THE EVENT OF AN EPIDEMIC}

\section{Summary}

The purpose of this article is to analyse the rights and obligations of parents resulting from the custody of the child, limited for the purposes of the research conducted to the issue of protecting the child's health and ensuring its safety. The duty of care, thus limited, is analysed in the context of the implementation of compulsory education in the situation of the epidemic caused by the SARS-CoV-2 virus. The issues raised in the article are part of the discussion on the determination of the limits of parents' interference in the necessity for the child to participate in compulsory schooling during an epidemic, when direct contact with a child attending school may cause a significant risk of infection. In a broader sense, the considerations deal with the problem of the child's health safety and that of family members who are less resistant to disease, assessed in terms of two general clauses: the best interests of the child and the good of the family.

Keywords: child good; family good; parental authority; care for the child; healthcare; duty to learn; SARS-CoV-2 virus 
